\title{
Nigerian Commercial Banks and Creative Accounting Practices
}

\author{
Beshiru Sanusi ${ }^{1}$, Prince Famous Izedonmi ${ }^{2}$ \\ ${ }^{1}$ United Bank for Africa Plc, Auchi Branch, Auchi, Nigeria \\ ${ }^{2}$ Faculty of Management Sciences, University of Benin, Benin City, Nigeria \\ Email: bashdgrate@yahoo.com, profizedonmi@yahoo.com
}

Received October 10, 2013; revised November 22, 2013; accepted December 19, 2013

Copyright (C 2014 Beshiru Sanusi, Prince Famous Izedonmi. This is an open access article distributed under the Creative Commons Attribution License, which permits unrestricted use, distribution, and reproduction in any medium, provided the original work is properly cited. In accordance of the Creative Commons Attribution License all Copyrights (C) 2014 are reserved for SCIRP and the owner of the intellectual property Beshiru Sanusi, Prince Famous Izedonmi. All Copyright (C) 2014 are guarded by law and by SCIRP as a guardian.

\section{ABSTRACT}

This study is an empirical investigation on the opinions of experienced staff of commercial banks on creative accounting practices in Nigerian commercial banks. To achieve the objective of this study research questions were raised, hypotheses formulated, and a review of related literature was made. The population of this study is the staff of commercial banks currently operating in Nigeria. Quota sampling technique was adopted for this study. The sample used consisted of the most experienced/senior 42 Managers/Assistant Managers and 42 Accountants/Assistant Accountants drawn from the twenty-one (21) consolidated commercial banks head office branches in Lagos state. The survey method of research design was adopted and the primary data were employed. The major instrument used for generating the primary data was the questionnaire, which was designed in five-response option of Likert-scale and administered on senior branch Managers/Assistant Managers and Accountants/Assistant Accountants of the commercial banks chosen for this study. The data generated for this study were analyzed through mean scores while the stated hypotheses were statistically tested with Z-test. Our findings revealed that, the major reason for creative accounting practices in Nigerian commercial banks is to boost the market value of shares; users of accounting information are adversely affected by this practice of creative accounting; Streamlining accounting principles and rules to reduce diversities of professional judgment in financial reporting will help minimize creative accounting practices. Therefore we recommended among others that creative accounting should be considered as a serious crime and as such accounting bodies, law courts and other regulatory authorities need to adopt strict measure to stop the practice.

\section{KEYWORDS}

Creative Accounting; Commercial Bank Distress

\section{Introduction}

Financial accounting reports are produced to show the true and fair state of affair of business entities so that stakeholders and other users of such information can take informed decision. However, current accounting practices allow a degree of choice of policies and professional judgment in determining the methods of measurement, criteria for recognition, and even the definition of the accounting entity. The exercise of this choice can involve a deliberate non-disclosure of information and manipulation of accounting figures, thereby making the business appear to be more profitable (or less profitable for tax purposes) and financially stronger than it is supposed to be. With this practice, users of accounting information are being misled and this constitutes a threat to corporate investment and growth $[1,2]$.

The corporate failures of most Nigeria commercial banks recently and the arrest of some banks Chief Executives by the Economic and Financial Crimes Commission (EFCC) are as a result of fraudulent financial reporting, 
which has affected the stability of the financial system [2]. In recent years, creative accounting practice has been on the increase in Nigerian commercial banks to attract unsuspecting investors, or obtain undeserved accountingbased rewards by presenting an exaggerated misleading or deceptive state of bank financial affairs. It is evident that the extent of window-dressing of banks' Financial Statement in Nigeria has greatly violated all known ethical standards of the accounting and auditing profession [3]. It is upon this background that this study seeks to provide an empirical investigation on the opinion of experienced staff of commercial banks on creative accounting practices in the Nigeria commercial banks.

This paper is structured into the following sections: introduction, conceptual framework/literature review, methodology, results/analysis, conclusion and recommendation.

\subsection{Statement of Problem}

Past studies on creative accounting such as Amat, Blake and Dowds (1999) as cited in [4-6], have focused mainly on the impact of creative accounting on investors' decisions in the stock market without highlighting the reasons for such practices. Moreover, the studies are of foreign origin and their findings may not be suitable for Nigeria considering environmental differences. Most of the available studies in Nigeria such as [1,7-9], did not pay particular attention to the banking industry. The few available studies that focused on the banking industry for instance [2] concentrated their works on banks in locations outside Lagos without giving consideration to the fact that the financial reports of banks are prepared at their head offices. Hence, this study is an attempt to fill existing gap by focusing on Commercial banks head office branches in Lagos.

\subsection{Research Questions}

The following questions were raised for this study:

1) What is the major reason for creative accounting practices in Nigeria commercial banks?

2) Does creative accounting have any impact on commercial banks distress in Nigeria?

3) Will streamlining accounting principles and rules to reduce diversities of professional judgement in financial reporting minimizes creative accounting practices in Nigeria commercial banks?

\subsection{Research Objectives}

The main objective of this study is to provide an empirical investigation on the opinion of experienced staff of commercial banks head office branches on creative accounting practices in the Nigeria commercial banks. Specifically, the study aimed at achieving the following:

1) To examine the reasons for creative accounting practices in Nigeria commercial banks.

2) To find out if creative accounting is the cause of commercial banks' distress in Nigeria.

3) To examine whether streamlining accounting principles and rules to reduce diversities of professional judgement in financial reporting can minimize creative accounting practices.

\subsection{Hypotheses}

The following hypotheses were formulated for the study:

1) The major reason for creative accounting practices in Nigeria commercial banks is not to boost the market value of shares.

2) Creative accounting has no significant effect on the recent commercial banks' distress in Nigeria.

3) Streamlining accounting principles and rules to reduce diversities of professional judgement in financial reporting will not minimize creative accounting practices.

\section{Conceptual Framework and Literature Review}

In order to ensure uniformity in the preparation and presentation of financial accounting reports, Generally Accepted Accounting Practices (GAAP) are prescribed within the accounting profession and the business world by regulatory agencies in the accounting profession, in Nigeria this include the Financial Reporting Council of Nigeria [formally Nigerian Accounting Standard Board). However, the accounting process and regulatory framework as prescribed by Accounting Standards, Companies and Allied Matters Act (CAMA 2004), Banks and Other Financial Institutions Act (BOFIA 2007), leave room for discretional judgments by the accountants. This involves resolving conflicts between competing approaches to the manner in which results of financial events 
and transactions are presented. [9] explained that this flexibility provides opportunity for manipulation, deceit and misrepresentation. These activities as negatively practiced by the less scrupulous elements of the accounting profession are popularly referred to as creative accounting. According to [10], Creative accounting is the transformation of accounting figures from what they actually are to what perpetrators desire by taking advantage of the existing rules and/ or ignoring some or all of them. The practices are characterized by excessive compilation and the use of novel ways of characterizing income, assets, or liabilities with the intent to influence readers towards the interpretations which are desired by the authors of the reports [10]. According to [8] this result in financial reports that are not all dull, but have all the complication of a novel, hence the term "creative". According to [9] while this practice is called creative accounting in UK, it is known as Earnings management in the USA. They further stressed that terms such as "aggressive" or "innovative" or "cosmetic" or "deceptive" accounting are also used in referring to creative accounting.

Creativity in corporate accounting may arise under at least three different financial market conditions. The first is when a company floats its shares to attract investors to subscribe to such share either at par or at a premium, depending on the financial market evaluation of the company's future prospects. The second is when the company whose shares are already listed in a stock exchange, wants to paint an attractive picture of its financial conditions so that the shares may be quoted at a premium. Finally, a company having its shares listed in the stock exchange may declare and pay high dividends based on inflated profits through overvaluation of assets, undervaluation of liabilities and change in system of stock valuation that may boost the image of the company at least in the short run. Unethical considerations in creative accounts have developed to such depths that terms like fraud audit and forensic accounting have gained currency and are becoming new professions. Accounting practitioners and auditors are increasingly required to appear in courts for deposition [2]. According to Jones (2011) as cited in [11] the difference between creative accounting and fraud is that creative accounting is working within the regulatory framework but fraud involves breaking the law or violating regulatory framework.

When positively viewed, it may seem that creative accounting connotes invention of accounting principles and techniques to recognize change in economic, social, political and business environments. But in reality, the term is not normally used in the positive, but negative, sense, although it might be both a blessing and a curse. It is a blessing when something new is created to refine the accounting system, and becomes an addition to the existing stock of accounting knowledge. Creative accounting becomes a curse, and therefore undesirable, when unethical elements enter the system. But real world experience reveals that it is in most cases practiced in an undesirable way to attract investors by presenting an exaggerated, sometimes misleading and deceptive state of an organization's financial affairs. This is why this system of accounting is sometimes referred to as "deceptive accounting" thus, two perspectives of this term may be identified. The first one recognizes genuine changes in the business accounting practices while the second one reflects undesirable window-dressing that tends to distort financial information. This second perspective is normally referred to as creative accounting Viadu \& Matis, 2012) [12]. Kamau, Mutiso and Ngui (2012) [13] associate creative accounting with any, or a combination, of the following actions: Creation of data, dressing up of documents, and cooking up of accounts. As Jameson (1988) as cited in [2] has rightly argued that accountants have an obligation to the organizations they serve, their profession, the public, and themselves to maintain the highest standards of ethical behaviour. They have a responsibility to be competent and to maintain confidentiality, integrity and objectivity.

According to [14], the professional accountant should be straight-forward, honest and sincere in his approaches to his professional work. This statement of the International Federation of Accountants (IFAC) is applicable to all professional accountants and auditors in the course of their professional duties. But this advice has greater significance to a person who is a member of a profession, because he represents not only himself but also the entire profession. The name and the reputation of a profession depend on the personal qualities of those who constitute the profession. An accountant should not allow personal prejudice or bias to override objectivity. When conveying information in financial statements, the accountant must maintain impartiality. Therefore, we may conclude that creative accounting in the context of this paper refers to accounting techniques in which financial information is distorted by window-dressing and various manipulations in order to present theoretically, a better financial picture by either increasing or reducing profit as the case may be, by giving a misleading appearance of capital size or structure and by concealing relevant information from existing or potential investors [2].

\subsection{Creative Accounting Techniques}

According to Amat, Blake and Dowds (1999) as cited in [7,15] the opportunities or potentials for creative accounting may be found in the following principal areas: 
1) Regulatory Flexibility: The accounting rules often permit a choice between different accounting methods. The international accounting standard for example, allows a company to choose between a policy of writing off development expenditure as it occurs and amortizing it over the life of the related project. A company can therefore choose the accounting policy that gives a preferred image;

2) Management discretionary position: Certain entries in the accounts involve an unavoidable degree of estimation, judgment, and prediction. In some, cases, such as the estimation of an asset's useful life made in order to calculate depreciation, these estimates are normally made inside the business and the creative accountant has the opportunity to err on the side of caution or optimism in making the estimate. In order for instance for managers to obtain the financial position and stability they assumed they can decide to increase or decrease provision for bad debts.

3) Artificial transactions are often entered into both to manipulate balance sheet amounts and to move profits between accounting periods. This is achieved by entering into two or more related transactions with an obliging third party, normally a bank. For example, supposing an arrangement is made to sell an asset to a bank then lease that asset back for the rest of its useful life. The sale price under such a 'sale and leaseback' can be pitched above or below the current value of the asset, because the difference can be compensated for by increased or reduced rentals.

4) Timing of Genuine transactions offers to the management the opportunity to increase the revenues when the operating profit is not satisfactory and to create the desired impression in the accounts. The existing stock of a company that has a significant higher value compared to the historic value may be sold only when the operating profit is not satisfactory.

\subsection{Reasons for Creative Accounting}

As cited in [16] a number of notable studies such as (Chen, 2007; Collingwood, 1991; Desai \& Dharmapala, 2006; Henry, 2004; Ningi, 2006) have investigated and gave the reasons why entities seek to manipulate their accounts, to include the following amongst others:

1) Income smoothing, borne out of the desire to report a steady trend of growth in profit rather than to show volatile profits with a series of dramatic rise and fall.

2) Manipulating reported profit/earning to match Profit Forecast, another variant of income smoothing. i.e. to manipulate profit to tie it to forecasts.

3) Income boosting Accounting Policy change, often made to distract attention from unwelcome news of the company's actual performance and ranking among peers.

4) Boosting/maintaining share price, with the effect of reducing the apparent level of borrowing and creating the appearance of a good profit trend hence positioning the company at advantage position for new share issues and takeover bids.

5) Directors' insider dealings involving delay in release of information for the market, to enhance their opportunity to benefit from inside knowledge;

6) Circumvent contractual rights, obligations and constraints, prevalent where companies are subject to various form of contractual rights, obligation and constraints based on the amount reported on the accounts;

7) Avoid Government Regulations, by choosing accounting methods that tend to reduce their reported profits;

8) Enhance Directors Bonus Scheme, where the scheme is linked to profit or the company's share price;

9) Profit sharing arrangement may induce choice of accounting methods to minimize declared profit to reduce claim on the company;

10) Tax savings purposes, where taxable income is measured in relation to the accounting figures;

11) Change in management with a motivation to shift responsibility for losses and poor performance to previous management.

\subsection{Effects of Creative Accounting}

The real causes of creative accounting lie in the conflicts of interest among different interest groups. Managing shareholders' interest is to pay less tax and dividends. Investor-shareholders are interested to get more dividends and capital gains. Country's tax authorities would like to collect more and more taxes. Employees are interested to get better salary and higher profit share. But creative accounting puts one group or two to advantageous position at the expense of others. Earnings per share (EPS), the only number to which investors often go wrong by 
paying too much attention, can be "boosted by the stroke of an accountant's creative pen" [2].

[5] in a speech before members of the Australian Society of Accountants, stressed that financial statements, which inflate the performances of companies by manipulating figures (i.e. through creative accounting) should be stamped out as it put the investor and other users of accounting information in great difficulties to distinguish between the paper entrepreneur and the truly successful entrepreneur. The message from this statement may now be stated to focus on the obvious effects of creative accounting: There are companies listed on the stock exchange, which show inflated profit and better financial position in their creative accounting statements to attract investors, this creation of accounts just misguides and creates confusion; some companies prospectus may not always depict the reality of the financial positions of the listed companies; processes adopted for created accounting statements may hold out untrue hopes to investors for a shorter period but cannot continue to succeed for a longer period; ultimately, the concerned companies listed in the stock exchange collapse and the investors lose confidence in them and stock market.

[1] sought to find out whether financial accounting information users in Nigeria are aware of creative accounting in the private sector of the economy. They carried out their study in Lagos, through field work questionnaire administered on practicing accountants from randomly selected audit firms. They found out that creative accounting has definitely affected information users. Hence in Nigeria it is believed that the practice of creative accounting is constructive to the benefit of the manipulator of accounts. They also found out that the genuinely positive aspect of the corporation is presented in its fullest proportion to the public, while the area of weakness is played down in reporting in anticipation of correcting the weakness. They further revealed that accounting bases, principles and processes should be streamlined to reduce diversities of human judgments on accounting issues.

A large number of literatures that viewed creative accounting from ethical perspective see it as fraud and therefore a challenge to the accounting profession. A study carried out by Amat, Blake and Dowds (1999) as cited in [4], titled "the ethics of creative accounting", showed that accountants accept the ethical challenge that creative accounting raises need to be aware of the scope for both abuse of accounting policy and manipulation of transactions. [4] found two categories of manipulative behavior: macro manipulation that is the lobbying of regulators to persuade them to produce regulations that is more favourable to the interest of the preparers of accounts. They found this to be pronounced in USA. The second one is the micro manipulation where the accounting figures are doctored to produce a bias view at the entity level. They observed this in large number in Spain. Both forms of behavior are morally reprehensible.

[6] found evidence of creative accounting by firms in Bangladesh which they traced to conflict of interest among different groups that the accountant wants to serve. Accounts are therefore prepared to serve the particular group the accountant wishes. They also found out that if creative accounting is practiced by any organization there is plenty of scope of manoeuvring and manipulation of accounting information, such manipulation might have the shareholders, public, the government and any interested party absolutely confused as to what is and what is not real and true in connection with a set of published accounting statements. They also stated that available evidence shows that the practice of creative accounting is global.

Oluba (2009) as cited in [3] observed that not a few banks in Nigeria are involved in creative accounting. He found that banks directly lend to stockbrokers to buy their own shares to sustain demand pressure thus causing continued price rise without corresponding appreciation in underlying values or fundamentals.

[2] investigated the reasons for creative accounting in the Nigeria banking industry through a field work questionnaire administration on staff of banks in Abuja. They found that the major reason for creative accounting practices in banks is to boost market value of shares. They also noted that accounting principles and rules should be streamlined to reduce diversities of professional judgment in financial reporting.

\section{Methodology}

The survey method of research design was adopted in this study. The population of the study is the staff of commercial banks in Nigeria. Quota sampling technique was adopted for this study and the sampled members consisted of forty two (42) branch managers/assistant managers (2 each per branch) and forty two (42) accountants/assistant accountants (2 each per branch) of the twenty one (21) consolidated commercial banks head office branches currently operating in Lagos state, giving a total sample size of 84 .

The main instrument used for the collection of data in this study was the questionnaire, which was designed in five response options of likert-scale (i.e. strongly agree, agree, disagree, strongly disagree and neutral). The questionnaire was administered on experienced/senior branch Managers/assistant managers and Accountants/ 
assistant accountants of the commercial banks chosen for this study.

The data generated for this study were analyzed using mean scores. The stated hypotheses were statistically tested using Z-test.

The formula for calculating $Z$ is as given below:

$$
Z=\frac{\bar{X}_{1}-\bar{X}_{2}}{\sqrt{\frac{\left(n_{1}-1\right)\left(S_{1}^{2}\right)+\left(n_{2}-1\right)\left(S_{2}^{2}\right)}{n_{1}+n_{2}-2}}\left[\frac{1}{n_{1}}+\frac{1}{n_{2}}\right]} \text { where; } Z=Z \text { test }
$$

$\bar{X}_{1}=$ mean of the sample of Managers

$\bar{X}_{2}=$ mean of the sample of Accountants

$S_{1}^{2}=$ variance of the sample of Managers

$S_{2}^{2}=$ variance of the sample of Accountants

$n_{1}=$ sample size of the Managers

$n_{2}=$ sample size of the Accountants

\section{Results and Analysis}

In this section we present the result of hypotheses testing and data analysis.

\section{Test of Hypotheses}

The hypotheses stated earlier in this study were tested using the Z-test.

1) The major reason for creative accounting practice in the Nigerian commercial banks is not to boost the market value of shares.

In testing this hypothesis, the data generated was used and the result obtained is presented in Table 1 (see Appendix).

Computed $\mathrm{Z}$ value $=4.04$ (see Appendix)

Decision: Reject $\mathrm{H}_{0}$, since Z-computed (4.04) is greater than Z-critical (1.96). This implies that the major reason for creative accounting practices in Nigerian commercial banks is to boost the market value of shares.

2) Creative accounting has no significant effect on commercial banks' distress in Nigeria.

To test this hypothesis, the data generated were used, and the result obtained is presented in Table 2 (see Appendix).

Computed $\mathrm{Z}$ value $=1.98$ (see Appendix)

Decision: Reject $\mathrm{H}_{0}$, since Z-computed (1.98) is greater than Z-critical (1.96). This implies that creative accounting has significant effect on commercial banks distress in Nigeria; hence its practices adversely affect users of accounting information.

3) Streamlining accounting principles and rules to reduce diversities of professional judgment in financial reporting will not minimize creative accounting practices.

In testing this hypothesis, data generated were used and result obtained is presented in Table 3 (see Appendix).

Computed $Z$ value $=6.19$ (see Appendix)

Decision: Reject $\mathrm{H}_{0}$, since Z-computed (6.19) is greater than Z-critical (1.96). This implies that Streamlining accounting principles and rules to reduce diversities of professional judgment in financial reporting will minimize creative accounting practices.

\section{Conclusions and Recommendations}

The results of our analysis revealed that creative accounting practices have significant effect on commercial banks distress in Nigeria and by implication adversely affect users of accounting information. Our survey report for this purpose indicated a means score of 3.69 which is greater than the expected means score of 3.00. This finding agrees with [5] who reported that creative accounting practices put the investor and other users of that accounting information to greater difficulties to distinguish between the paper entrepreneur and the truly suc- 
cessful entrepreneur.

It was also observed that the major reason for the practices of creative accounting in Nigeria commercial banks is to boost the market value of shares. Our analysis on this issue revealed a mean score 3.73, which is equally greater than 3.00, the expected mean score. This finding also lends support to [2] who found that the major reason for the practices of creative accounting in Nigeria banking industry is to boost shares value. This result does not also differ from the work of Collingwood (1991) as cited in [16] who claimed that creative accounting is being practiced particularly to enhance share prices.

Finally, the result of our analysis indicated that streamlining accounting principles and rules to reduce diversities of professional judgment in financial reporting will minimize creative accounting practices. Our analysis for this purpose showed a mean score of 3.45, which is greater than the expected means score of 3.00. This finding lend support to $[1,2]$, who revealed that accounting bases, principles and processes should be streamlined in order to reduce diversities of human judgments on accounting issues.

Based on the findings from this study, the following recommendations are made:

1) Accounting principles and rules should be streamlined to reduce diversities of professional judgment in financial reporting; we believe that the adoption of International Financial reporting standard in Nigeria will go a long way to settle this matter.

2) Creative accounting practices should be considered as a criminal offence and therefore accounting bodies, law courts and other regulatory authorities need to adopt strict measures to stop the practice and punish offenders.

3) Accountants in Nigeria commercial banks and other sectors in general should uphold high ethical standards and maintain integrity in all their professional dealings. They need to ensure that the accounting profession rest on ethical principles and values, commanding national and international respect and confidence, by stopping the evil practice of creative accounting.

4) Commercial bank auditors should be independent, straight forward, honest and sincere in their approaches to professional work. They should not allow personal prejudice or bias to override the principle of objectivity in the profession.

5) Regulators should engage the service of Forensic Accountants to review the accounts of commercial banks regularly.

\section{REFERENCES}

[1] B. C. Osisioma and J. A. Enahoro, “Creative Accounting and Option of Total Quality Accounting in Nigeria,” Journal of Global Accounting, Vol. 2, No. 1, 2006, pp. 5-15.

[2] C. Akenbor and E. Ibanichuka, "Creative Accounting Practices in Nigerian Banks,” An International Multidisciplinary Journal, Ethiopia, Vol. 6, No. 3, 2012, pp. 23-34.

[3] H. O. Osazevbaru, “Creative Accounting and Firm’s Market Value in Nigeria,” Kuwait Chapter of Arabian Journal of Business and Management Review, Vol. 2, No. 3, 2012, pp. 38-50.

[4] O. Amat and C. Gowthorpe, “Creative Accounting: Nature, Incidence and Ethical Issues,” Journal of Economic Literature Classification: M41, 2010, pp. 11-15.

[5] H. Domash, "How to Detect Creative Accounting: Detecting Accounting Shenanigans," 2002. http:/www.winninginvesting.com

[6] D. K. Sen and E. L. Inanga, “Creative Accounting in Bangladesh and Global Perspective,” 2005. http://www.allbusiness.com

[7] J. A. Aremu and M. Bello, “Creative Accounting and Financial Scandals,” International Journal of Accountancy, Vol. 17, No. 2, 2004, pp. 142-147.

[8] N. S. Ezeani, M. I. Ogbonna, E. M. Ezemoyih and E. C. Okonye, “The Effect of Creative Accounting on the Job Performance of Accountants (Auditors) in Reporting Financial Statement in Nigeria," Kuwait Chapter of Arabian Journal of Business and Management Review, Vol. 1, No. 9, 2012, pp. 3-12.

[9] A. A. Idris, J. S. Kehinde, S. S. Ajemunigbohun and J. S. Gabriel, “The Nature, Techniques and Prevention of Creative Accounting: Empirical Evidence from Nigeria,” Canadian Journal of Accounting and Finance, Vol. 1, No. 1, 2012 , pp. 26-31.

[10] S. Ghosh, “Creative Accounting: A Fraudulent Practice Leading to Corporate Collapse," Research and Practice in Social Sciences, Vol. 6, No. 1, 2010, pp. 1-15.

[11] A. L. Ibanichuka and J. U. Ihendinihu, "Evaluation of the Impact of Creative Accounting Techniques on Reported Financial Performance of Firms in Nigeria,” Nigerian Journal of Economic and Financial Research, Vol. 2, No. 1, 2009 , p. 131.

[12] A. B. Viadu and V. Matis, “Corporate Governance and Creative Accounting: Two Concepts Strongly Connected? Some Inter- 
esting Insights Highlighted by Constructing the Internal History of a Literaturem,” Annales Universitatis Apulensis Series Oeconomica, Vol. 12, No. 1, 2010, pp. 332-342.

[13] C. G. Kamau, A. N. Mutiso and D. M. Ngui, “Tax Avoidance and Evasion as a Factor Influencing Creative Accounting Practice among Companies in Kenya,” Journal of Business Studies Quarterly, Vol. 4, No. 2, 2012, pp. 77-84.

[14] International Federation of Accountants, “IFAC Handbook 2012: Code of Ethics for Professional Accountants,” IFAC, New York, 2012, pp. 13-14.

[15] J. Largay, “Lessons from Enron,” Accounting Horizons, Vol. 16, No. 2, 2002, pp. 153-156. http://dx.doi.org/10.2308/acch.2002.16.2.153

[16] A. L. Ibanichuka and J. U. Ihendinihu, "Creative Accounting and Implication for Dividend Payout of Companies in Financial Sub-Sector of Nigeria Economy,” Mediterranean Journal of Social Sciences, Vol. 3, No. 15, 2012, pp. 132-134.

\section{Appendix}

Table 1. Z-Test computations for test of hypothesis 1.

\begin{tabular}{|c|c|c|c|c|c|c|c|c|c|c|c|c|}
\hline \multirow[b]{2}{*}{ Responses } & \multicolumn{6}{|c|}{ Managers' Group } & \multicolumn{6}{|c|}{ Accountants' Group } \\
\hline & Scores (x) & Frequencies (f) & $f x$ & $(x-x)$ & $(x-\bar{x})^{2}$ & $f(x-\bar{x})^{2}$ & Scores (x) & Frequencies (f) & $f x$ & $(x-x)$ & $(x-x)^{2}$ & $f(x-x)^{2}$ \\
\hline SA & 5 & 22 & 110 & 0.79 & 0.624 & 13.730 & 5 & 7 & 35 & 1.76 & 3.10 & 21.68 \\
\hline A & 4 & 11 & 44 & -0.21 & 0.044 & 0.485 & 4 & 12 & 48 & 0.76 & 0.58 & 6.93 \\
\hline $\mathrm{D}$ & 3 & 6 & 18 & -1.21 & 1.464 & 8,785 & 3 & 10 & 30 & -0.24 & 0.06 & 0.58 \\
\hline SD & 2 & 2 & 4 & -2.21 & 4.884 & 9.768 & 2 & 10 & 20 & -1.24 & 1.54 & 15.38 \\
\hline $\mathrm{N}$ & 1 & 1 & 1 & -3.21 & 10.304 & 10.304 & 1 & 3 & 3 & -2.24 & 5.02 & 15.05 \\
\hline Total & - & 42 & 177 & - & - & 43.072 & - & 42 & 136 & - & - & 59.67 \\
\hline
\end{tabular}

Source: Survey Data, April 2013. $\bar{X}_{1}=4.21, \bar{X}_{2}=3.24, S_{1}^{2}=1.03, S_{2}^{2}=1.42, n_{1}=42, n_{2}=42$

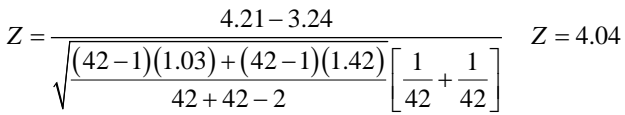

Table 2. Z-Test computations for test for hypothesis II.

\begin{tabular}{|c|c|c|c|c|c|c|c|c|c|c|c|c|}
\hline \multirow[b]{2}{*}{ Responses } & \multicolumn{6}{|c|}{ Managers' Group } & \multicolumn{6}{|c|}{ Accountants' Group } \\
\hline & Scores $(\mathrm{x})$ & Frequencies (/) & $f x$ & $(x-x)$ & $(x-\bar{x})^{2}$ & $f(x-\bar{x})^{2}$ & Scores (x) & Frequencies (f) & $f x$ & $(x-x)$ & $(x-x)^{2}$ & $f(x-x)^{2}$ \\
\hline SA & 5 & 13 & 65 & 1.05 & 1.10 & 14.33 & 5 & 10 & 50 & 1.57 & 2.46 & 24.65 \\
\hline A & 4 & 20 & 80 & 0.05 & 0.0025 & 0.05 & 4 & 8 & 32 & 0.57 & 0.32 & 2.60 \\
\hline $\mathrm{D}$ & 3 & 5 & 15 & -0.95 & 0.903 & 4.51 & 3 & 7 & 31 & -0.43 & 0.18 & 1.29 \\
\hline SD & 2 & 2 & 4 & -1.95 & 3.80 & 7.61 & 2 & 14 & 28 & -1.43 & 2.04 & 28.63 \\
\hline $\mathrm{N}$ & 1 & 2 & 2 & -2.95 & 8.70 & 17.41 & 1 & 3 & 3 & -2.43 & 5.90 & 17.71 \\
\hline Total & - & 42 & 166 & - & - & 33.91 & - & 42 & 144 & - & - & 74.88 \\
\hline
\end{tabular}

Source: Survey Data, April 2013. $\bar{X}_{1}=3.95, \bar{X}_{2}=3.43, S_{1}^{2}=0.81, S_{2}^{2}=1.78, n_{1}=42, n_{2}=42$ 
$Z=\frac{3.95-3.43}{\sqrt{\frac{(42-1)(0.81)+(42-1)(1.78)}{42+42-2}\left[\frac{1}{42}+\frac{1}{42}\right]}} \quad Z=1.98$

Table 3. Z-Test computations for test for hypothesis III.

\begin{tabular}{|c|c|c|c|c|c|c|c|c|c|c|c|c|}
\hline \multirow[b]{2}{*}{ Responses } & \multicolumn{6}{|c|}{ Managers' Group } & \multicolumn{6}{|c|}{ Accountants' Group } \\
\hline & Scores $(\mathrm{x})$ & Frequencies (/) & $f x$ & $(x-x)$ & $(x-\bar{x})^{2}$ & $f(x-\bar{x})^{2}$ & Scores $(\mathrm{x})$ & Frequencies (f) & $f x$ & $(x-x)$ & $(x-x)^{2}$ & $f(x-x)^{2}$ \\
\hline SA & 5 & 19 & 95 & 0.81 & 0.656 & 12.47 & 5 & 6 & 30 & 2.29 & 5.24 & 31.46 \\
\hline A & 4 & 16 & 64 & -0.19 & 0.0361 & 0.58 & 4 & 8 & 32 & 1.29 & 1.66 & 13.31 \\
\hline $\mathrm{D}$ & 3 & 4 & 12 & -1.19 & 1.416 & 5.66 & 3 & 13 & 39 & 0.29 & 0.084 & 1.09 \\
\hline SD & 2 & 2 & 4 & -2.19 & 4.796 & 9.59 & 2 & 11 & 22 & -0.71 & 0.50 & 5.55 \\
\hline $\mathrm{N}$ & 1 & 1 & 1 & -3.19 & 10.176 & 10.18 & 1 & 4 & 4 & -1.71 & 2.92 & 11.70 \\
\hline Total & - & 42 & 176 & - & - & 38.48 & - & 42 & 114 & - & - & 63.11 \\
\hline
\end{tabular}

Source: Survey Data, April 2013. $\bar{X}_{1}=4.19, \bar{X}_{2}=2.71, S_{1}^{2}=0.92, S_{2}^{2}=1.50, n_{1}=42, n_{2}=42$

$Z=\frac{4.19-2.71}{\sqrt{\frac{(42-1)(0.92)+(42-1)(1.50)}{42+42-2}}\left[\frac{1}{42}+\frac{1}{42}\right]} \quad Z=6.19$

\section{List of Commercial Banks in Nigeria as at April 2013}

1. Access Bank

2. Citibank

3. Diamond Bank

4. Ecobank Nigeria

5. Enterprise Bank Limited-Formerly Spring Bank

6. Fidelity Bank Nigeria

7. First Bank of Nigeria

8. First City Monument Bank

9. Keystone Bank Limited

10. Guaranty Trust Bank

11. Mainstreet Bank Limited

12. Savannah Bank

13. Skye Bank

14. Stanbic IBTC Bank Nigeria Limited

15. Standard Chartered Bank

16. Sterling Bank

17. Union Bank of Nigeria

18. United Bank for Africa

19. Unity Bank Plc.

20. Wema Bank

21. Zenith Bank

Source: Global banking and financial review

(www.globalbankingandfinance.com/list-of-commercial-banks-in-nigeria) 